\title{
HALAL RISK PRIORITY IN FOOD SUPPLY CHAIN MANAJEMEN BASED ON A TECHNOLOGY PERSPECTIVE
}

\author{
Hana Catur Wahyuni ${ }^{1}$, Wasito ${ }^{2}$ \\ ${ }^{1}$ Industrial engineering, Universitas Muhammadiyah Sidoarjo \\ ${ }^{2}$ Management, STIE Muhammadiyah Tuban
}

Halal is a main requirement for Muslims in food selection. On the other hand, the increasing Muslim population in the world also encourages an increase in the availability of halal food. In its development, driven by technological advances, there is a risk of changes in halal food. These changes can occur in the food supply chain that involves various aspects. This study aims to identify risks based on technological aspects (technoware, humanware, infoware, orgaware). Furthermore, this study also aims to prioritize halal risk using the AHP method. The results showed that the type of transportation, cooperation, shipping schedule and supplier legality are sub criteria that are priority in arranging corrective actions in preventing halal risk.

Keywords: Halal, Risk, Food supply chain

Halal menjadi syarat utama bagi umat Islam dalam pemilihan makanan. Di sisi lain, meningkatnya populasi Muslim di dunia juga mendorong peningkatan ketersediaan makanan halal. Dalam perkembangannya, didorong oleh kemajuan teknologi, ada risiko perubahan makanan halal. Perubahan tersebut dapat terjadi pada rantai pasok pangan yang melibatkan berbagai aspek. Penelitian ini bertujuan untuk mengidentifikasi risiko berdasarkan aspek teknologi (technoware, humanware, infoware, orgaware). Selanjutnya, penelitian ini juga bertujuan untuk memprioritaskan risiko halal dengan menggunakan metode AHP. Hasil penelitian menunjukkan bahwa jenis transportasi, kerjasama, jadwal pengiriman dan legalitas pemasok merupakan sub kriteria yang diprioritaskan dalam menyusun tindakan korektif dalam mencegah risiko halal.

\section{OPEN ACCESS}

ISSN 2528-4649 (online) ISSN 2338-4409 (print) Reviewed by Andrianto \& Zarah Puspitaningtyas\& Vinola Herawaty

Received:25 Juli 2020 Accepted:28 Agustus 2020 Published:30 September 2020

Hana Catur Wahyuni1, Wasito2 Halal Risk Priority In Food Supply

Chain Manajemen Based On A Technology Perspective JBMP

6:2.doi: 10.21070/jbmp.v6i2.356
Kata Kunci: Halal, Risk, Food supply chain 


\section{INTRODUCTION}

The development of the Muslim population in the world has increased very significantly. It is estimated that the average growth rate reaches $1.5 \%$ per year. This percentage is higher when compared to non-Muslim growth, only $0.7 \%$ per year (Pew Research Center's Forum on Religion \& Public Life). The Muslim population will reach $26.4 \%$ of the total world population which is projected to be 8.3 billion in 2030 . More than fifty countries are countries with a majority Muslim population. The largest Muslim population lives in Southeast Asia, while the countries in the Middle East and North Africa are only $20 \%$ of the total.

The increase in the muslim population is associated with an increase in the need for halal food. This is because halal is a mandatory requirement for Muslims in choosing food consumed. This condition is in accordance with the Qur'an of Surah Al-Maidah 88: "And eat food that is lawful again good than what Allah has blessed you, and fear Allah whom you believe in Him". More than that, at present, the availability of halal food is a necessity for non-Muslims. This phenomenon occurs because non-Muslims view halal as a healthy and safe food consumption trend compared to non-halal food products [1]. This is an opportunity for companies to market halal products to Muslim and non-Muslim consumers [2] [3].

For this reason, currently various Muslim or nonMuslim countries are developing halal guarantee systems. This system aims to provide assurance that food consumed by consumers has met the halal element. In Korea, it is demonstrated through the availability of halal certificates issued by the Korean Muslim Federation (Yonhap News Agency) for all food products. $\mathrm{n}$ various countries, institutional system management of halal management has been made.

Table 1. Halal institutions

But, in fact, this opportunity has not been accompanied by a commitment to keep food halal when accepted by end consumers. This can be seen from the occurrence of several changes in food status from halal to non-halal in the supply chain process. Sales of nonhalal meat to Muslims by the Birmingham wholesale market, pork content in lamb burgers at Leicester school (halalhmc.org). These events indicate that there is a risk of changing food status from halal to non-halal in some processes, for example in the logistics process, transportation system and storage in warehouses [4]. This problem was triggered because food producers did not fully understand halal risks in the food supply chain. Most producers understand that halal is focused on raw materials that do not contain materials that are prohibited by Islam. Meanwhile, other halal aspects, such as: transportation, distribution, storage have not received attention.

Along with a touch of technology starting from the procurement of raw materials, production processes, and distribution results in increasingly difficult for consumers to ensure the halal of a product. This is triggered by the use of various kinds of additional materials in the production process, distribution system and increasingly complex marketing systems. Basically, the concept of halal in the supply chain is different from the conventional supply chain concept. Halal in the supply chain requires specific and specific policies especially to ensure halal integrity from sources to consumers about supply chain objectives, logistics control systems, supply chain business processes, supply chain resources, and supply chain performance matrices [5]. Halal integration in the supply chain begins with the use of raw materials that are in accordance with the concept of halal, halal processes, such as slaughter, storage and logistics systems that are not contaminated with non-halal products [6].

In its implementation, the success of companies in implementing halal in the supply chain is driven by (1) government support factors in the form of halal industry promotion, halal certification authority, incentives for halal business, and funding for halal research, (2) dedicated assets, which are related to separation of halal and non-halal products during the distribution process, warehousing and other equipment, (3) information technology that can improve performance and efficiency and expand supply chain networks, (4) collaboration relationships, vertically (suppliers) and horizontally (external parties, competitors or non-competitors), (5) halal certification, (6) halal treacibility [7].

In the development of halal in the supply chain [8], it begins with consumer confidence in halal products. That is, consumers buy halal products based only on a sense of trust that the products sold / offered by sellers are halal products. Furthermore, it will develop in the halal direction based on certification of the products being marketed. The complete development (evolution) of halal is as follows:

Table 2. Halal evolution in supply chains

With the development of the concept of halal in the supply chain, the problem of the risk of changing the status of halal to non-halal also began to develop. The more activities in the supply chain process, the higher the chance of halal risk. The following table provides an overview of the various types of halal risk along the supply chain that have been carried out by previous researchers:

Table 3. Halal risk in supply chain.

Various types of halal risks that threaten the food supply chain, require every business actor to get preventive measures. Utilization of technology is one solution that can be used. Without technology, there will be difficulties in determining halal status because of the limited ability to identify it [13]. Technology will enable the emergence of the latest innovations related to halal authentication so as to ensure food products are in harmony with the halal principle [14]. Utilization of 
technology will help determine the halal of the product effectively and efficiently, especially in the process, especially in the process of authentication and verification, for example in the detection of mixing pig products and their derivatives [15].

This study aims to identify halal risk based on technological aspects and determine risk priorities. The results of the study are expected to be used by business managers as information about insight into halal in the supply chain, then able to arrange strategic steps to avoid or reduce these risks.

\section{METHOD}

This study uses AHP (Analytical Hierarchy Process) to determine risk priorities. AHP is AHP is a decision making tool by considering various criteria based on the level of importance [16]. In previous research, AHP has been used to prioritize risks in various contexts. Dong et al [17] have developed the AHP concept to arrange risk priorities based on ordering in the supply chain at telecommunications equipment and service companies. [18] use AHP to compare various kinds of risks in the supply chain in various products with criteria of quality, price, continuity of supply, supplier service, and buyer supplier pathership. [19] use AHP to determine corrective measures to strengthen the risk management system at ports in China, which include: service risk, operational risk, port linkage process risk, and external environmental risk.

This method is used to find the most important criteria for each component of the technology, with the following steps:

- Begin by formulating $\mathrm{C}=\{\mathrm{Cj} / \mathrm{j}=1,2, \ldots \mathrm{n}\}$ criteria. Where the scale of comparison (pairwaise comparison) for $\mathrm{n}$ criteria arranged in a matrix $\mathrm{A}$ $(n \times n)$ with aij $(i, j=1,2, \ldots n)$ is the weight of each.

- Next, each matrix is normalized to find the relative weight, which is called eigenvactor (w) and is related to eigenvalue ( $\lambda$ mak) through the following equation:

$$
A_{w}=\lambda_{\max } \cdot \mathrm{W}
$$

- For answers that are more consistent, the value of mak tends to approach n. Saaty (1980) has developed a consistency index to measure consistency judgment when making comparisons by formulating a consistency index $(\mathrm{CI})$ as:

$$
C I=\frac{\lambda_{\text {mak }}-n}{(n-1)}
$$

- The CI $=0$ index reflects "pairwise comparision" of perfect consistent judgment. Then a CR (Consistency Ratio Index) index is developed which is defined as the comparison of CI for a particular judgment with the CI of "random judgment". Saaty has suggested that CRs should be below $10 \%(0.1)$ to show that the "value judgment" given is acceptable, and if necessary requires a revision or review.

\section{RESULTS AND DISCUSSION}

The case study of this research was conducted on the supply of prawn crackers produced by a company in East Java, Indonesia. The company was founded in 1979 and currently has more than 500 workers. This company is classified as a medium-sized company that is developing. His commitment to implementing halal standards is very strong, as evidenced by the cooperation with the Indonesian Ulema Council (MUI) in implementing the halal concept. The supply chain system in this company is illustrated in the following figure:

Fig 1 Supply chain process

Data collection is performed on experts who have been experimenting in this field. Retrieval of data with questionnaires that use a comparison scale [20] as follows:

Table 5. Scale for pairwaise comparison

The AHP structure model used in this study is as follows:

Fig 2 AHP stucture

The results of the questionnaire obtained are arranged in a comparison matrix. This matrix shows the value of the comparison of the importance level of sub criteria in each technology criteria. The matrix arranged based on the results of the questionnaire is shown in the following table:

Table 6. Comparison matrix between sub criteria

Then weighting is calculated for each sub-criterion for technological criteria. The calculation results are shown in the following figure:

Table 7. Sub-criteria weighting matrix on technoware criteria

Furthermore, calculations are performed to determine the consistency index value (CI) of the technoware as the formula in the previous explanation. The calculation results show the CI value for technoware is 0 , then the comparison value is considered consistent. With the same calculation, the priority weighting values for humanware, infoware and orgaware at halal risk are as follows:

Tabel 8. Halal risk weighting

The results of the study as shown in table 6 show that for technoware, the highest weight of halal risk is in the T1 criterion. The highest weight for humanware is in $\mathrm{H} 2$ 
criteria and the highest weight for infoware is in criterion I1. As for the software, the highest weight is in the $\mathrm{O} 1$ criteria. The highest weight value in each criterion shows the priority of the risk of halal contamination. For this reason, the highest weight for each technology criterion is the priority of improvement in the preparation of preventive measures.

\section{DISCUSSION}

In the techoware criteria, the type of vehicle used by suppliers to deliver raw materials is the highest risk of halal contamination. This happens when raw materials are sent using the same type of vehicle as non-halal products. This condition results in the mixing of halal and non-halal products. Before being used for acceleration, vehicles must be cleaned of unclean, separate transportation systems for halal and nonhalal animals (based on animal type or slaughtering process) [4].

In humanware, supplier collaboration capability is a top priority that needs to be considered in halal risk subscriptions. This is related to the ability of suppliers to understand halal requirements for raw materials that will be sent to the company. Entrants must be able to understand the halal requirements in accordance with the halal guarantee system used in order to keep the raw materials halal at the producer. The ability of suppliers to implement halal requirements will determine the occurrence of such contamination. For example, suppliers who do not understand the process of slaughtering animals in a halal manner will result in a change in the status of halal to become halal.

Schedule delivery of supplier raw materials is a top priority in the risk of halal contamination. This condition can occur if the supplier does not have a planned schedule in the shipping process. Without a planned schedule, delivery is not structured. As a result of this, the choice of vehicle type, transport process etc. will be carried out without regard to halal requirements. This condition triggers a mixture of halal and non-halal products.

Supplier legality is the main priority of halal risk on the software criteria. Supplier legality is an institutional halal recognition held by the supplier. Usually halal legality is issued by government institutions that regulate the halal system, for example MUI in Indonesia, Jakim in Malaysia. With the halal certificate at the supplier, the company (consumer) automatically has obtained a guarantee that the product sent is halal. To get the halal certificate, the supplier will be inspected by an institution that handles halal certification. At present, some food companies use halal certificates to select suppliers.

\section{CONCLUSION}

Halal is an important aspect for Muslims in choosing food. This is related to the Muslim obligation to eat halal food. On the other hand, currently halal food is also a demand for nonMuslims, because halal food is considered to provide a guarantee of food safety for consumption. Therefore, the development of the halal food industry has experienced rapid progress in recent periods.

To guarantee halal food, technology can be utilized. The development of technology is able to make the early detection of the halal of a product. Technology makes it easy for humans to identify food content for non-halal materials, speeding up the production process (eg halal slaughtering, halal delivery). Technology will speed up the process and keep the product halal in the hands of consumers.

This study uses four technological criteria, namely technoware, humanware, infoware and orgaware. The type of transportation, cooperation, shipping schedule and supplier legality are sub criteria that are priority in arranging corrective actions in preventing halal risk. The technical implications of this research are that it can be used by business players in the food industry to develop improvement strategies to maintain halal products.

\section{REFERENCES (Using format APA. example:)}

[1] Ismail, F.H., Nasiruddin, K., Samad, N.S. 2017. "Halal and Non Muslim: What Matters". International Journal of Accounting \& Business Management, Vol 5 (2), pp 1-13.

[2] Nurrachmi, R. 2017. "The Global Development of Halal Food Industry: a Survey". Tazkia Islamic Finance and Business Review, Vol 11 (1), 39- 56.

[3] Wilkins, S., Butt, M.M., Shams, S., Perez, A. 2019. "The Acceptance of Halal Food in Non Muslim Countries: Effect of Religious Indentity, National Identification, Consumer Ethnocentrism and Consumer Cosmopolitanism". Journal of Islamic Marketing, Vol 10 (4), pp 1308- 1331,

[4] Tieman, M., Ghazali, C.M. 2014. "Halal control activities and assurance activities in halal food logistics". ProcediaSocial and Behavioral Sciences 121, 44-57.

[5] Tieman M., Van Der Vorst J.G.A.J., Che Ghazali M., 2012. Principles In Halal Supply Chain Management, Journal Of Islamic Marketing, Vol 3 No 3, pp 217- 243.

[6] Soon, Y., Nathoo, F.S., Masson, M.E.J., 2017. “A Bayesian approach to the mixed-effects analysis of accuracy data in repeated-measures designs". Journal of Memory and Language, 97, 78-92.

[7] Ab Thalib M.S., Abdul Hamid A.B, Zulfikar M.H., 2015. "Halal Supply Chain Critical Succes Factors: A Literatur Review", Journal Of Islamic Marketing, Vol 6 Issue 1, pp 134.

[8] Tieman M, (2011), "The Application Of Halal Supply Chain Management: In Depth Interview", Journal Of Islamic Marketing, Vol 2 No 2, pp 186-195.

[9] Yaacob, T.Z., Rahman, F.A., Jaafar, H.S. 2018. "Risk Categories In Halal Food Transportation: A Preliminary Findings". International Journal Supply Chain Management, Vol 7 No 6, pp 453- 463.

[10] Olya, H, G.T., Al- Ansi, M. 2018. "Risk Assesment of Halal Product and Service: Implication for Tourist Industry". Tourism Management, 65, pp 279- 291.

[11] Fujiwara, T., Ismlail, R.,M. 2018. "Supplier Management System in Halal Food Supply Chain: A Case Study Approach". International Journal of Supply Chain Management, vol 7 No 3, pp 216- 220. 
[12] Handayani, D.I., Haryono., Prihatiningsih, T. 2019. "Application of Grey Theory Method For Halal Risk Food Assesment Based on The Traceability System In Food Supply Chain". Advances in Intelligent System Research, 171, pp 426- 434.

[13] Salahudin, A., Ramli, M.A., Zulkepli, M.I.Z., Razak, M.IA. 2017. "Issues in Halal Meat Product and Authentication Technology From Islamic Perspectives" International Journal of Academic Research in Business and Social Sciences, Vol 7, No 12, pp 1305- 1315.

[14] Lubis, H.N., Naim, N.F.M., Alizul, N.N., Ahmed, M.,U. 2016. "From Market to Food Plate: Current Trusted Technology and Innovations in Halal Food Analysis". Trends in Food Science \& Technology, 58, pp 55- 68.

[15] Fadzlillah, N.A., Che Man, Y.B., Jamaludin, M.A., Ab Rahman, S. 2012. "The Contribution of Science and Technology in Determining the Permissibility". Revelation and Science, Vol 2, No 2, pp 1-8.

[16] Khan, S., Abd Haleem., Khan, M.I. 2019. "Proritising

Conflict of InterestStatement:Theauthorsdeclarethat theresearchwas conducted in the absence of any commercial or financial relationships that could be construed as a potential conflict of interest.

Copyright (C) $x x x x$ (isi tahun terbit) 1 and 2 dst. This is an open-access article dis- the Risk in Halal Food Supply Chain: an MCDM Approach”. Journal of Islamic Marketing

[17] Dong, Q., Cooper, O. 2016. “An Order of Magnitude AHP Supply Chain Risk Assesment Framework". International Journal of Production Economics, 182, pp 144156.

[18] Mital, M., Del Guidice, M., Papa, A. 2018. "Comparing Supply Chain Risk For Multiple Product Categories With Cognitive Mapping and Analytical Hierarchi Process (AHP)". Technological Forecasting \& Social Change, 131, pp 159170 .

[19] Jiang, B., Li, J., Shen, S. 2018. "Supply Chain Risk Assesment and Control of Port Enterprises: Qingdao Port as Case Study". The Asian Journal of Shipping and Logistic, vol 34 iss 3, pp 198- 208.

[20] Saaty, T.L., 1980. The Analytic Hierarchy Process: Planning, Priority Setting, Re- source Allocaton. McGrawHill, NewYork.

tributed under the terms of the Creative Commons Attribution License (CC BY). The use, distribution or reproduction in other forums is permitted, provided the original author(s) and the copyright owner(s) are credited and that the original publication in this journal is cited, in accordance with accepted academic practice. No use, distribution or reproduction is permitted which does not comply with these terms. 


\begin{tabular}{|l|l|l|}
\hline \multicolumn{1}{|c|}{ Countries } & \multicolumn{1}{c|}{ Institution } & \multicolumn{1}{c|}{ Standar/guideline } \\
\hline Indonesia & LPPOM MUI & Halal assurance system \\
\hline Malaysia & JAKIM & MS1500:2004 \\
\hline Singapura & $\begin{array}{l}\text { Majlis Ugama Islam atau Islamic } \\
\text { Religious Council Of Singapore }\end{array}$ & $\begin{array}{l}\text { Halal Quality Management System } \\
\text { (HalMQ) }\end{array}$ \\
\hline Thailand & CICOT & THS24000:2552 \\
\hline Jepang & Japan Halal Assosiation (JHA) & International Halal Alliance \\
\hline United Arab Emirates & GCC & $\begin{array}{l}\text { GSO0933:1998; GSO1931/2009; } \\
\text { UAE993:1998 }\end{array}$ \\
\hline Negara Eropa & CEN & Guidelin on halal definition \\
\hline Austria & ASI & ONR 14200:2009 \\
\hline
\end{tabular}

\begin{tabular}{|c|c|c|c|}
\hline Phase Name & Muslim Company & Halal Product & Halal Supply Chain \\
\hline $\begin{array}{l}\text { Characteristic of halal } \\
\text { supply chain }\end{array}$ & Based on trust & $\begin{array}{l}\text { Based on local halal standard } \\
\text { source is halal certified }\end{array}$ & $\begin{array}{l}\text { Based on complex set of } \\
\text { local, regional and } \\
\text { international } \\
\text { Halal standards } \\
\text { International } \\
\text { Halal manufacturing } \\
\text { and distribution zones } \\
\end{array}$ \\
\hline $\begin{array}{l}\text { Issues in Halal } \\
\text { supply chains }\end{array}$ & $\begin{array}{l}\text { Lack of Halal } \\
\text { certification } \\
\text { authority } \\
\text { Halal integrity } \\
\text { concerns on } \\
\text { imports } \\
\end{array}$ & $\begin{array}{l}\text { Efficiency of Halal } \\
\text { certification } \\
\text { Transparency of Halal } \\
\text { standard } \\
\text { Lack of Halal certified } \\
\text { ingredients }\end{array}$ & $\begin{array}{l}\text { Halal standards are not } \\
\text { harmonised } \\
\text { Lack of certified logistics } \\
\text { service providers }\end{array}$ \\
\hline $\begin{array}{l}\text { Example } \\
\text { countries }\end{array}$ & $\begin{array}{l}\text { Many countries } \\
\text { in the Middle } \\
\text { East, Africa, } \\
\text { Asia and } \\
\text { Eastern Europe }\end{array}$ & $\begin{array}{l}\text { GCC countries, Indonesia, } \\
\text { Singapore, Thailand, } \\
\text { the USA, Canada, France, } \\
\text { The Netherlands, } \\
\text { Australia, New Zealand, } \\
\text { Bosnia, the UK }\end{array}$ & $\begin{array}{l}\text { Malaysia and Brunei are in } \\
\text { the early stage of phase } 3\end{array}$ \\
\hline
\end{tabular}

\begin{tabular}{|l|l|l|}
\hline \multicolumn{1}{|c|}{ Author, year } & \multicolumn{1}{|c|}{ Risk Aspect } & \multicolumn{1}{c|}{ Risk Category } \\
\hline Yaacob el al, 2018 [9] & Transportation & $\begin{array}{l}\text { Delay risk, opeartional risk, } \\
\text { natural hazard, technology } \\
\text { adoption risk, halal integrity } \\
\text { risk. }\end{array}$ \\
\hline Olya et al, 2018 [10] & Product and service & $\begin{array}{l}\text { Health risk, physicological } \\
\text { risk, enviromental risk, social } \\
\text { risk, quality risk, financial } \\
\text { risk, time risk }\end{array}$ \\
\hline Fujiwara et al, 2018 [11] & Supplier management & $\begin{array}{l}\text { Risk consequence, supply } \\
\text { risk source, risk driver, risk } \\
\text { mitigating strategy, }\end{array}$ \\
\hline Handayani et al, 2019 [12] & Halal treaceability system & $\begin{array}{l}\text { The addition of prohibited } \\
\text { additives, the contamination } \\
\text { of the waste of lizards, } \\
\text { miceand cockroaches, and the } \\
\text { unsuitability of food } \\
\text { additives }\end{array}$ \\
\hline
\end{tabular}




\begin{tabular}{|c|c|c|c|}
\hline Criteria & Supply Chain & Sub kriteria & Code \\
\hline \multirow{8}{*}{ Technoware } & \multirow[b]{2}{*}{ Supplier } & type of transportation & T1 \\
\hline & & $\begin{array}{l}\text { Equipment for the process of } \\
\text { moving raw materials }\end{array}$ & $\mathrm{T} 2$ \\
\hline & \multirow{4}{*}{ Production } & machine type & T3 \\
\hline & & Maintenance proces & $\mathrm{T} 4$ \\
\hline & & Inspection process & T5 \\
\hline & & Quality process & T6 \\
\hline & \multirow{2}{*}{ Distibutor } & Distribution warehouse & $\mathrm{T} 7$ \\
\hline & & Types of vehicles for distribution & T8 \\
\hline \multirow{7}{*}{ Humanware } & \multirow{2}{*}{ Supplier } & Dicipline & H1 \\
\hline & & Coorperation & $\mathrm{H} 2$ \\
\hline & \multirow{3}{*}{ Production } & Tim work & $\mathrm{H} 3$ \\
\hline & & Target orientation & $\mathrm{H} 4$ \\
\hline & & Leadhership & H5 \\
\hline & \multirow{2}{*}{ Distributor } & Distribution plan & H6 \\
\hline & & Commitment & $\mathrm{H} 7$ \\
\hline \multirow{7}{*}{ Infoware } & Supplier & Delivery schedule & I1 \\
\hline & \multirow{5}{*}{ Production } & Information system & $\mathrm{I} 2$ \\
\hline & & Networking & I3 \\
\hline & & Decision supplort system & I4 \\
\hline & & Communication & I5 \\
\hline & & Update information acces & I6 \\
\hline & Distributor & $\begin{array}{l}\text { Information system for } \\
\text { distribution }\end{array}$ & $\mathrm{I} 7$ \\
\hline \multirow{6}{*}{ Orgaware } & Supplier & Supplier legality & O1 \\
\hline & \multirow{4}{*}{ Production } & Legality company & $\mathrm{O} 2$ \\
\hline & & Strategic plan & $\mathrm{O} 3$ \\
\hline & & Productivity & $\mathrm{O} 4$ \\
\hline & & company's competitive & O5 \\
\hline & Distributor & Distributor legality & O6 \\
\hline
\end{tabular}

\begin{tabular}{|c|l|l|}
\hline $\begin{array}{c}\text { Intensity of } \\
\text { important }\end{array}$ & \multicolumn{1}{|c|}{ Definition } & \multicolumn{1}{c|}{ Explanation } \\
\hline 1 & Equal importance & Two activities contribute equally to the objective \\
\hline 3 & $\begin{array}{l}\text { Moderate } \\
\text { importance }\end{array}$ & Experience and judgment slightly favor one activity over another \\
\hline 5 & Strong importance & Experience and judgment strongly favor over another \\
\hline 7 & Very strong & $\begin{array}{l}\text { An activity is favored very strongly over another; its dominance } \\
\text { demonstrated in practice }\end{array}$ \\
\hline 9 & $\begin{array}{l}\text { Extreme } \\
\text { importance }\end{array}$ & $\begin{array}{l}\text { Theevidencefavoringoneactivityoveranotherisofthehighestpossibleor } \\
\text { derofaffirmation }\end{array}$ \\
\hline $2,4,6,8$ & $\begin{array}{l}\text { For compromise } \\
\text { between the } \\
\text { above values }\end{array}$ & $\begin{array}{l}\text { Sometimes one needs to interpolate a compromise judgment } \\
\text { numerically because there is no good word to describe it }\end{array}$ \\
\hline
\end{tabular}




\begin{tabular}{|c|c|c|c|c|c|c|c|c|}
\hline Sub criteria & T1 & T2 & T3 & T4 & T5 & T6 & T7 & T8 \\
\hline T1 & 1.00 & 2.87 & 2.60 & 3.40 & 5.60 & 5.40 & 5.40 & 1.77 \\
\hline T2 & 0.35 & 1.00 & 1.27 & 1.64 & 4.00 & 4.00 & 4.24 & 0.84 \\
\hline T3 & 0.38 & 0.79 & 1.00 & 2.40 & 3.40 & 2.80 & 5.40 & 0.89 \\
\hline T4 & 0.29 & 0.61 & 0.42 & 1.00 & 2.00 & 2.80 & 4.00 & 1.72 \\
\hline T5 & 0.18 & 0.25 & 0.29 & 0.50 & 1.00 & 1.29 & 2.07 & 0.55 \\
\hline T6 & 0.19 & 0.31 & 0.36 & 0.36 & 0.78 & 1.00 & 2.47 & 0.93 \\
\hline T7 & 0.19 & 0.24 & 0.19 & 0.25 & 0.48 & 0.40 & 1.00 & 0.94 \\
\hline T9 & 0.56 & 0.19 & 1.12 & 0.58 & 1.82 & 1.08 & 1.06 & 1.00 \\
\hline Total & 3.14 & 7.26 & 7.25 & 10.13 & 19.09 & 17.97 & 25.64 & 8.64 \\
\hline
\end{tabular}

\begin{tabular}{|c|c|c|c|c|c|c|c|c|c|c|c|}
\hline $\begin{array}{c}\text { Sub } \\
\text { criteria }\end{array}$ & $\mathrm{T} 1$ & $\mathrm{~T} 2$ & $\mathrm{~T} 3$ & $\mathrm{~T} 4$ & $\mathrm{~T} 5$ & $\mathrm{~T} 6$ & $\mathrm{~T} 7$ & $\mathrm{~T} 8$ & Total & Wieght & $\begin{array}{c}\text { Eigen } \\
\text { value }\end{array}$ \\
\hline $\mathrm{T} 1$ & 0.32 & 0.40 & 0.36 & 0.34 & 0.29 & 0.30 & 0.21 & 0.20 & 2.42 & 0.30 & 8 \\
\hline $\mathrm{T} 2$ & 0.11 & 0.14 & 0.18 & 0.16 & 0.21 & 0.18 & 0.17 & 0.10 & 1.24 & 0.15 & 8 \\
\hline $\mathrm{T} 3$ & 0.12 & 0.11 & 0.14 & 0.24 & 0.18 & 0.16 & 0.21 & 0.10 & 1.25 & 0.16 & 8 \\
\hline $\mathrm{T} 4$ & 0.09 & 0.08 & 0.06 & 0.10 & 0.10 & 0.16 & 0.16 & 0.20 & 0.95 & 0.12 & 8 \\
\hline $\mathrm{T} 5$ & 0.06 & 0.03 & 0.04 & 0.05 & 0.05 & 0.07 & 0.08 & 0.06 & 0.45 & 0.06 & 8 \\
\hline $\mathrm{T} 6$ & 0.06 & 0.04 & 0.05 & 0.04 & 0.04 & 0.06 & 0.10 & 0.11 & 0.49 & 0.06 & 8 \\
\hline $\mathrm{T} 7$ & 0.06 & 0.03 & 0.03 & 0.02 & 0.03 & 0.02 & 0.04 & 0.11 & 0.34 & 0.04 & 8 \\
\hline $\mathrm{T} 9$ & 0.18 & 0.16 & 0.16 & 0.06 & 0.10 & 0.06 & 0.04 & 0.12 & 0.87 & 0.11 & 8 \\
\hline Total & 1.00 & 1.00 & 1.00 & 1.00 & 1.00 & 1.00 & 1.00 & 1.00 & 8.00 & 1.00 & 64 \\
\hline
\end{tabular}

\begin{tabular}{|c|c|c|c|c|c|c|c|}
\hline Criteria & Code & Weigth & $\begin{array}{c}\text { Risk } \\
\text { Priority }\end{array}$ & Criteria & Code & Weigth & $\begin{array}{c}\text { Risk } \\
\text { Priority } \\
\end{array}$ \\
\hline \multirow{8}{*}{ Technoware } & $\mathrm{T} 1$ & 0.30 & 1 & \multirow{8}{*}{ Infoware } & I1 & 0.30 & 1 \\
\hline & $\mathrm{T} 2$ & 0.15 & 3 & & $\mathrm{I} 2$ & 0.12 & 3 \\
\hline & $\mathrm{T} 3$ & 0.16 & 2 & & $\mathrm{I} 3$ & 0.17 & 2 \\
\hline & $\mathrm{T} 4$ & 0.12 & 4 & & I4 & 0.11 & 4 \\
\hline & T5 & 0.06 & 6 & & I5 & 0.11 & 5 \\
\hline & T6 & 0.06 & 7 & & I6 & 0.10 & 6 \\
\hline & $\mathrm{T} 7$ & 0.04 & 8 & & I7 & 0.09 & 7 \\
\hline & $\mathrm{T} 8$ & 0.11 & 5 & & & & \\
\hline \multirow{7}{*}{ Humanware } & $\mathrm{H} 1$ & 0.19 & 2 & \multirow{7}{*}{ Orgaware } & $\mathrm{O} 1$ & 0.31 & 1 \\
\hline & $\mathrm{H} 2$ & 0.25 & 1 & & $\mathrm{O} 2$ & 0.19 & 3 \\
\hline & $\mathrm{H} 3$ & 0.14 & 3 & & $\mathrm{O} 3$ & 0.20 & 2 \\
\hline & $\mathrm{H} 4$ & 0.12 & 4 & & $\mathrm{O} 4$ & 0.10 & 5 \\
\hline & $\mathrm{H} 5$ & 0.10 & 6 & & O5 & 0.11 & 4 \\
\hline & H6 & 0.11 & 5 & & O6 & 0.09 & 6 \\
\hline & $\mathrm{H} 7$ & 0.09 & 7 & & & & \\
\hline
\end{tabular}



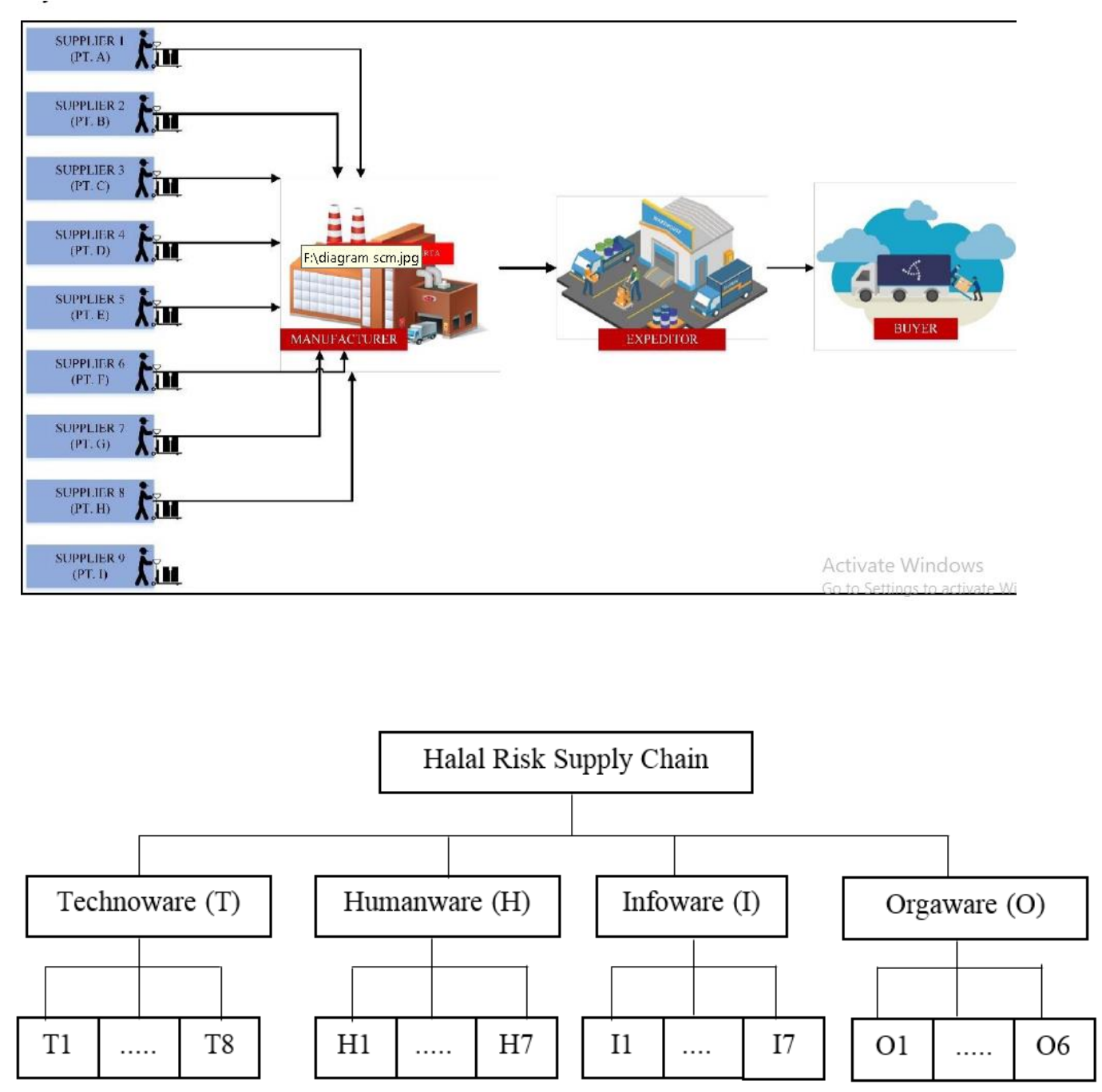